US and Soviet academicians meet in Washington

\section{Washington}

THE US National Academy of Sciences and the Academy of Sciences of the USSR last week announced plans for a joint committee to study the global ecology. The agreement coincided with a visit by a 16-member delegation from the Soviet Academy to the United States that was cut short by the earthquake in Armenia.

The impetus for the new committee, according to a report prepared earlier this month by a working group drawn from the two academies, was an awareness that the "problem of global ecological security that confronts all humankind has increased greatly in its seriousness". Increased use of natural resources, population growth and increased production of greenhouse gases all pose serious problems. "The global ecosystem is being degraded rapidly", according to the report, "so that its sustainability is being called into question." The new committee will meet once or twice a year to consider plans for studying the situation, and devising recommendations for steps to slow the deterioration. The committee will assist in bilateral activities, as well as with multinational efforts such as the International Geosphere/Biosphere Program.

The visit by the Soviet delegation began with a speech at the US academy's headquarters in Washington by Soviet academy president Guriy Marchuk. Marchuk spoke of how Mikhail Gorbachev's plans for restructuring Soviet society - perestroika will affect the scientific community.

In practical terms, Marchuk pointed to mandatory retirement for academicians at age 75. Although they will retain most membership rights and perquisites, academicians over 75 will no longer hold administrative posts. There are also competitive elections for the leadership posts at scientific institutes.

Marchuk says that half of Soviet institutes are now headed by "young people". He went on to suggest that the best ideas usually come to scientists before they are $\mathbf{3 0}$ years old. Perhaps noticing the expressions on the faces of his audience, Marchuk quickly added, "Of course, there are some exceptions here".

Marchuk called the renewed emphasis on economics one of the biggest changes wrought by perestroika. At first, Marchuk said, scientists were not prepared to find the tools to contribute to the process of perestroika, but, he said, that is now changing. He also stressed that perestroika is directed toward humanitarian goals and humanity. "Everything should be done for the benefit of man", Marchuk said.

Joseph Palca

\title{
New clinical trial programme for AIDS in the United States
}

\section{Washington}

IN an attempt to widen access to clinical trials of experimental AIDS treatments and bolster confidence in the clinical trial process, the US National Institute of Allergy and Infectious Diseases (NIAID) late last month announced the creation of a new community-based clinical trial programme. Under the new programme, community physicians and clinics will systematically monitor their patients who are receiving experimental therapies and report the results to NIAID. In this way, NIAID hopes to offer the benefits of new drugs to more minorities and intravenous drug abusers, who are often under-represented in clinical trials, and encourage greater compliance with clinical trial rules.

Lack of adherence to the set protocol has been a problem in many clinical trials of AIDS drugs, especially when protocols called for control groups to receive only a placebo. People with AIDS often mistrust the motives of AIDS researchers, but join clinical trials because it is the best way to obtain promising drugs.

Some clinical trial participants, desperate for a cure, have supplemented the drug they were receiving with unproven drugs available on the black market, such as dextran sulphate and AL-721 (see Nature 335, 485; 6 October 1988), confounding the trial results.

Community-based organizations, such as the Community Research Initiative led by Tom Hannan in New York City, have had a greater level of compliance in clinical trials. But most of the community groups consist of middle-class homosexual men, who are better organized than the other groups most affected by the AIDS epidemic. Results obtained from trials involving primarily homosexual males may not apply to the population at large.

The NIAID programme will attempt to make use of existing community groups, while encouraging others to form. One resource that may be fruitfully exploited is drug-abuse treatment centres and public health clinics, where people with AIDS often enter the health-care system. Lawrence Deyton, the NIAID researcher who will be leading the project, says these centres will need guidance on how to study AIDS treatments.

To this end, part of the $\$ 6$ million devoted to the NIAID programme in 1989 will be used to assist community physicians to work out scientifically sound clinical research protocols.

Deyton says community groups and physicians will be able to apply for funds to study whatever drug they wish, but NIAID will guide the programme so that valid data are collected. In some cases, Deyton says, the community-based trials could even substitute for some of the studies required by the US Food and Drug Administration (FDA) for approval of a drug. NIAID will supply the drug to be studied to the community group or physician.

Most of the large community groups formed in response to the AIDS epidemic are expected to support the programme. Martin Delaney of the San Francisco AIDS education group Project Inform says he intends to submit an application to participate. But he says the test of the programme's efficacy will be whether the money really goes to local community groups, and not to the university clinical research centres who are conducting most of the current clinical trials.

Deyton says he will require all applicants to the programme to provide letters of endorsement from the community they serve to prove that they are truly representative of the community's interests.

The panel which will review the community applications will also be composed of "true peers", Deyton says, including people with AIDS as well as scientists and pharmaceutical company representatives.

Perhaps the largest obstacle facing the programme will be the paucity of basic health care in the inner-city slums that are often hardest hit by the AIDS epidemic. Anthony Fauci, director of NIAID, says this problem is "even more complex than I would have imagined", because it points up basic faults in the US health-care system. Fauci says he will try to focus discussion within the government on how the US Public Health Service can better cope with the problems caused by AIDS.

Carol Ezzell

- The US Food and Drug Administration last week approved a test kit for the presence of antibodies to HIV, the virus causing AIDS, that gives results in only five minutes. The test consists of envelope proteins from HIV bound to latex particles, which visibly agglutinate when antibody is present.

The test is intended primarily for use in physicians' offices, and will not replace the immunoassay tests now used to screen blood donated to blood banks because it has a higher rate of false positive results.

The HIV proteins used in the kit are produced by genetic engineering techniques by Cambridge BioScience, a Massachusetts biotechnology company. Cambridge BioScience licensed the patent for the gp120 envelope protein of HIV from Harvard University earlier this year (see Nature 331, 649; 1988). The kits will be sold by Baxter Health Care Corporation. $\square$ 